\title{
Assessing the Arab Spring in Libya and Syria: A Compilation of Varying Statements from Key Actors
}

\section{Charles Simpson *}

\section{Introduction}

The situations in Syria in February 2012 and in Libya in 2011 have provided the two most recent case studies in assessing a wide variety of international topics including NATO's future role in global security, the Responsibility to Protect (R2P) as a normative guide, the role of the League of Arab States (LAS) in the post-Arab Spring world, and the role of emerging powers on the United Nations Security Council (UNSC). Given the rapid proliferation of academic and professional examinations of the 2011 Libya and 2012 Syria cases, there appears a need for a compilation of the varying policies, resolutions, actions, and statements made by all relevant actors in both scenarios. The table below attempts to provide such a compilation in a concise and clearly structured format.

Charles Simpson is presently working as a research intern at the Geneva Centre for Security Policy. He is studying International Affairs and Middle East Studies at Northeastern University in Boston, Massachusetts. He has also studied at the School of International Training in Amman, Jordan, and Doğuş University in Istanbul, Turkey. 


\begin{tabular}{|c|c|}
\hline Position on Libya & Position on Syria \\
\hline \multicolumn{2}{|l|}{ Group 1 - International Organizations } \\
\hline \multicolumn{2}{|c|}{ Actor - United Nations Security Council (UNSC) } \\
\hline $\begin{array}{l}\text { - Pressure on Qaddafi began with UN } \\
\text { Security Council Resolution (UNSCR) } \\
1970 \text { (26 February 2011), imposing sanc- } \\
\text { tions on Libya consisting of an "arms } \\
\text { embargo," "travel ban," "asset freeze," } \\
\text { and "humanitarian assistance." } \\
\text { - Adopted UNSCR } 1973 \text { ( } 17 \text { March } \\
\text { 2011) authorizing "all necessary } \\
\text { measures to protect civilians ... while } \\
\text { excluding a foreign occupation force of } \\
\text { any form on any part of Libyan territory," } \\
\text { based on Chapter VII of the UN Charter. } \\
\text { This was passed in a vote of ten in favor, } \\
\text { none against, with five abstentions. This } \\
\text { provided the mandate for NATO } \\
\text { Operation Unified Protector ( } 22 \text { March } \\
\text { 2011). } \\
\text { - Reinforced UNSCR } 1970 \text { with } \\
\text { UNSCR } 2009 \text { (19 September } 2011 \text { ), and } \\
\text { also "looks forward to the establishment } \\
\text { of an inclusive, representative transitional } \\
\text { Government of Libya" while "reaffirming } \\
\text { its previous resolutions } 1674 \text { (2006) and } \\
1894 \text { (2009) on the protection of civilians } \\
\text { in armed conflict."4 } \\
\text { • Recognized the new transitional } \\
\text { government by "taking note of [the] } \\
\text { National Transitional Council's 'Decla- } \\
\text { ration of Liberation' of } 23 \text { October } 2011\end{array}$ & $\begin{array}{l}\text { - UNSC draft resolution was presented (4 } \\
\text { October 2011) condemning "grave and } \\
\text { systematic human rights violations" in Syria and } \\
\text { included "reference to Article } 41 \text { of the United } \\
\text { Nations Charter," which could allow for } \\
\text { application of sanctions. No specific mention of } \\
\text { sanctions was made, however. } \\
\text { - UN General Assembly passed Resolution } \\
2443 \text { ( } 19 \text { December } 2011 \text { ) "strongly } \\
\text { condemning" the Assad government. } \\
\text { - A second UNSC draft resolution was } \\
\text { presented (4 February 2012) "expressing grave } \\
\text { concern at the deterioration of the situation in } \\
\text { Syria," "noting the announced commitments by } \\
\text { the Syrian authorities to reform," "condemn[ing] } \\
\text { the continued widespread and gross violations of } \\
\text { human rights and fundamental freedoms by the } \\
\text { Syrian authorities," "demand[ing] that the Syrian } \\
\text { government immediately put an end to all human } \\
\text { rights violations," and "demand[ing] that the } \\
\text { Syrian government ... protect its population." } \\
\text { However, this draft resolution does not mention } \\
\text { pillar two or three of R2P, nor does it make any } \\
\text { suggestion of military intervention. It was vetoed } \\
\text { by Russia and China, with the other thirteen } \\
\text { UNSC member states voting in favor. }\end{array}$ \\
\hline
\end{tabular}

1 UN Security Council Resolution 1970, 26 February 2011; available at http://daccess-ddsny.un.org/doc/UNDOC/GEN/N11/245/58/PDF/N1124558.pdf?OpenElement.

2 UN Security Council Resolution 1973, 17 March 2011; avaialble at http://daccess-ddsny.un.org/doc/UNDOC/GEN/N11/268/39/PDF/N1126839.pdf?OpenElement.

3 Operation Unified Protector Final Mission Statistics, Fact Sheet, North Atlantic Treaty Organization Press \& Media Section Media Operations Centre (Brussels, 2011); available at http://www.nato.int/nato_static/assets/pdf/pdf_2011_11/20111108_111107-factsheet_up_ factsfigures_en.pdf.

4 UN Security Council Resolution 2009, 19 September 2011; available at http://daccess-ddsny.un.org/doc/UNDOC/GEN/N11/502/44/PDF/N1150244.pdf?OpenElement. 
in Libya" with UNSCR 2016 (27 October 2011). 5

- Called for stabilization and deproliferation of arms in Libya with UNSCR 2017, by "recognizing the urgent need for additional efforts to be made at the national, regional, and international levels, in order to prevent the proliferation of all arms" (31 October 2011). ${ }^{6}$

- "Welcoming the establishment of the transitional Government of Libya" in UNSCR 2022 (2 December 2011), thus expanding the National Transitional Council's (NTC) legitimacy to govern. ${ }^{7}$

Actor - League of Arab States (LAS)

- Suspended the Libyan delegation from participation in the League Council (22 February 2011). ${ }^{9}$

- Called on the UNSC "to take the necessary measures to impose immediately a no-fly zone on Libyan military aviation" to "provide the Libyan people with ... necessary protection" in response to "violations and grave crimes committed by the Libyan authorities, which have consequently lost their legitimacy," with LAS Resolution (LASR) 7360 (12 March 2011). ${ }^{10}$

- Recognized the NTC as the legitimate government of Libya by affirming an

- LAS suspended Syria's participation in the League Council in protest of the Assad government's attacks on civilians (16 November 2011). ${ }^{12}$

- Passed LASR 7441 launching an observer mission to Syria (24 November 2011). ${ }^{13}$ The observation mission was suspended on 29 January 2012 due to prohibitive levels of violence. $^{14}$

- $\quad$ Passed LASR 7442 (27 November 2011) to impose sanctions on Syria, specifically to "ban the travel of top Syrian officials," stop "transactions with the Central Bank of Syria," halt "governmental trade transactions with the Syrian government," and freeze "the financial as-

5 UN Security Council Resolution 2016, 27 October 2011; available at http://daccess-ddsny.un.org/doc/UNDOC/GEN/N11/567/10/PDF/N1156710.pdf?OpenElement.

6 UN Security Council Resolution 2017, 31 October 2011; available at http://daccess-ddsny.un.org/doc/UNDOC/GEN/N11/573/33/PDF/N1157333.pdf?OpenElement.

7 UN Security Council Resolution 2022, 2 December 2011; available at http://daccess-ddsny.un.org/doc/UNDOC/GEN/N11/620/28/PDF/N1162028.pdf?OpenElement.

8 UN Security Council Draft Resolution, 4 February 2012 (minutes of the $6711^{\text {th }}$ meeting of the UNSC); available at http://daccess-dds-ny.un.org/doc/UNDOC/PRO/N12/223/56/PDF/ N1222356.pdf?OpenElement.

9 Dominic Evans, "Syrian Forces Break up Hama Protest Marking Killings," Reuters (3 February 2012); available at http://af.reuters.com/ article/worldNews/idAFL6E8C52E220120203? $\mathrm{sp}=$ true.

10 League of Arab States Resolution 7360, "The outcome of the Council of the League of Arab States meeting at the ministerial level," Cairo, 12 March 2011; available at http://responsibilitytoprotect.org/Arab League Ministerial level statement 12 march 2011 english (1).pdf. 


\begin{tabular}{|c|c|}
\hline $\begin{array}{l}\text { NTC representative in the LAS Council } \\
(27 \text { August 2011). }\end{array}$ & $\begin{array}{l}\text { sets of the Syrian government." } 15 \\
\text { - Called for the "formation of a national unity } \\
\text { government," for "the international community } \\
\text { to show support to the National Unity Govern- } \\
\text { ment," and for the Assad regime to "withdraw all } \\
\text { manifestation of military activity" with LASR } \\
7444 \text { and } 7445 \text { ( } 22 \text { January } 2012) .{ }^{16} \\
\text { - Passed LASR } 7446 \text { (12 February 2012) } \\
\text { calling for an UN-Arab League peacekeeping } \\
\text { operation in Syria, citing the "responsibility to } \\
\text { protect civilians" as the cause. }{ }^{17} \text { The Syrian } \\
\text { government has rejected the proposed } \\
\text { peacekeeping mission. }\end{array}$ \\
\hline \multicolumn{2}{|l|}{ Actor - European Union (EU) } \\
\hline $\begin{array}{l}\text { - Represented the largest foreign donor } \\
\text { to address the humanitarian crisis in } \\
\text { Libya ( } 25 \text { February 2011). }{ }^{19} \\
\text { - The EU went beyond humanitarian }\end{array}$ & $\begin{array}{l}\text { - Imposed an embargo on Syria covering } \\
\text { "equipment which might be used for internal } \\
\text { repression," an "import ban on crude oil and } \\
\text { petroleum products," "restrictions on admission }\end{array}$ \\
\hline
\end{tabular}

11 League of Arab States Resolution 7370, "The Situation in Libya," Cairo, 27 August 2011; available at $\mathrm{http} / / /$ arableagueonline.org/wps/wcm/connect/1b53548048e9ef94b16bfd7abaae 88c3/\%D9\%82\%D8\%B1\%D8\%A7\%D8\%B1+7370.pdf?MOD=AJPERES.

12 Sheikh Hamad bin Jassem bin Jabr al-Thani, League of Arab States Official Press Release Statement, Cairo (13 November 2011); available at www.chinadaily.com.cn/world/2011-11/ 13/content_14085036.htm.

13 Muhammad Ahmad Mustafa al-Dabi, "Report of the Head of the League of Arab States Observer Mission to Syria for the period from 24 December 2011 to 18 January 2012," Cairo, 27 January 2012; available at www.innercitypress.com/LASomSyria.pdf.

14 “Amid Violence, Arab League Suspends Observer Mission in Syria," CNN (28 January 2012); available at http://edition.cnn.com/2012/01/28/world/meast/syria-unrest/index.html? $\mathrm{hpt}=\mathrm{hp} \mathrm{t} 3$.

15 League of Arab States Resolution 7442, "Following the Developments of the Situation in Syria," Cairo, 27 November 2011; available at http://www.openbriefing.org/regionaldesks/ middleeast/resolution7442.

16 League of Arab States Resolution 7444, "On the developments of the situation in Syria and the elements of the Arab Roadmap to solve the Syrian Crisis," Cairo, 22 January 2012; available at www.arableagueonline.org/wps/wcm/connect/76a9db8049e4238ba551bd526698d42c/ res+7444.pdf?MOD=AJPERES.

17 League of Arab States Resolution 7446, "Follow-up Developments on the Worsening Situation in Syria," Cairo, 12 February 2012; available at http://arableagueonline.org/wps/wcm/ connect/dbd065804a2433d984769c526698d42c/7446.pdf?MOD=AJPERES.

18 H. Zein, "Syria Rejects Decisions of AL Ministerial Meeting as Flagrant Interference in Syria's Affairs \& Encroachment on its National Sovereignty," Sana Syria News Agency (14 February 2012); available at www.sana.sy/eng/21/2012/02/14/400175.htm.

19 European Union Press Release, "Crisis in Libya: European Commission Allocates $€ 3$ Million to Address Humanitarian Needs,” Brussels, 25 February 2011; available at http://europa.eu/ $\mathrm{rapid} /$ pressReleasesAction.do?reference $=\mathrm{IP} / 11 / 228$. 
aid by imposing sanctions (28 February 2011) prohibiting the "direct or indirect supply, sale or transfer of arms," travel restrictions, and freezing of assets related to the Qaddafi government. ${ }^{20}$ These sanctions aligned with, and went beyond, the sanction framework established with UNSCR 1970 (2 March 2011). ${ }^{21}$

- The EU authorized the potential deployment of EUFOR "in support of humanitarian assistance operations" based on the Protection of Civilian measures cited in UNSCR 1970 and 1976 (1 April 2011). The UN has not yet requested EUFOR deployment. $^{22}$

- The EU was not initially unified in its member states' levels of support for intervention in Libya, as witnessed by German abstention from voting on UNSCR 1970 (26 February 2011), ${ }^{1}$ and French unilateral recognition of the of certain persons," and the "freezing of funds and economic resources of certain persons, entities and bodies," initiated in 2011 and reaffirmed in January 2012. ${ }^{23}$

- These measures conflict with earlier efforts to expand trade relations with Syria as outlined in the EU 2007-2013 Strategy Paper, and the fact that the EU is Syria's primary trading partner. $^{24}$

- Recent developments in Syria have delayed the implementation of EU-Syrian economic and political cooperative agreements. ${ }^{25} \mathrm{Up}$ until around 2008, EU-Syria relations were positive and showed signs of greater participation in Euro-Mediterranean partnerships. ${ }^{26}$ Conversely, present day EU statements have supported LAS and UN calls to "increase the international pressure on the Syrian regime," and welcome any "proposals to stop the violence [and] alleviate the suffering of the Syrian population." 27

20 European Union, Council Decision 2011/137/CFSP concerning restrictive measures in view of the situation in Libya, Brussels, 28 February 2011; available at http://eur-lex.europa.eu/ LexUriServ/LexUriServ.do?uri=OJ:L:2011:058:0053:0062:EN:PDF.

21 European Union, Council Regulation No.204/2011, Brussels, 2 March 2011; available at http://eur-lex.europa.eu.

22 European Union, Council Decision 2011/210/CFSP, Brussels, 1 April 2011; available at http://eur-lex.europa.eu/LexUriServ/LexUriServ. do?uri=OJ:L:2011:089:0017:0020:en:PDF.

23 European Union Restrictive Measures (Sanctions) in Force (Brussels, 2012); available at www.google.ch/url?sa $=\mathrm{t} \& \mathrm{rct}=\mathrm{j} \& \mathrm{q}=$ european commission - restrictive measures restrictive measures in force \&source=web\&cd=1\&ved=0CCIQFjAA\&url=http $\% 3 \mathrm{~A} \% 2 \mathrm{~F} \% 2 \mathrm{Feeas}$. europa.eu\%2Fcfsp\%2Fsanctions\%2Fmeasures.htm\&ei=5fg4T8LoOKrf4QT517WhCw\&usg.

24 European Commission, European Neighborhood and Partnership Instrument: Syrian Arab Republic: Strategy Paper 2007-2013 \& National Indicative Programme 2007-2010 (Brussels: European Commission, 2007); available at http://ec.europa.eu/world/enp/pdf/country/ enpi_csp_nip_syria_en.pdf.

25 Bilateral Agreement, Council of the European Union, "Cooperation Agreement between the European Economic Community and the Syrian Arab Republic," L269 (Brussels: Official Journal of the European Communities, 1977); available at http://ec.europa.eu/world/ agreements/prepareCreateTreatiesWorkspace/treatiesGeneralData.do?step $=0 \&$ redirect $=$ true \& treatyId $=255$.

26 Council of the European Union, Barcelona Process: Union for the Mediterranean Ministerial Conference (Marseille: Consilium Press Office, 2008); available at www.consilium.europa.eu/ueDocs/cms_Data/docs/pressData/en/misc/103733.pdf.

27 European Union, Statement by High Representative Catherine Ashton on the decisions by the League of Arab States on Syria, Brussels, 13 February 2012; available at www.consilium.europa.eu/uedocs/cms_data/docs/pressdata/EN/foraff/127953.pdf. 


\begin{tabular}{|c|c|}
\hline $\begin{array}{l}\text { NTC's legitimacy (10 March 2011), } \\
\text { but the EU's minimal role in the conflict } \\
\text { prevented policy fissures on these issues. }\end{array}$ & \\
\hline \multicolumn{2}{|l|}{ Actor - African Union (AU) } \\
\hline $\begin{array}{l}\text { The AU supported sanctions on Libya } \\
\text { in UNSCR } 1970 \text { (26 February 2011) and } \\
\text { supported UNSCR 1973's R2P mission } \\
\text { calling for "protection of civilians and the } \\
\text { cessation of all hostilities," from an ad } \\
\text { hoc panel on the Libya situation ( } 25 \\
\text { March 2011). }\end{array}$ & $\begin{array}{l}\text { - Official statements claim that media } \\
\text { depictions of violence amount to "misleading } \\
\text { campaigns conducted by some media to tarnish } \\
\text { Syria's image," and call for "solidarity between } \\
\text { the Arab and African peoples." Opposition } \\
\text { groups are reported as terrorists (22 October } \\
\text { 2011). }\end{array}$ \\
\hline \multicolumn{2}{|l|}{ Actor-Gulf Cooperation Council (GCC) } \\
\hline $\begin{array}{l}\text { - Issued a statement basically restating } \\
\text { and voicing support for UNSCR } 1970 . \\
\text { The GCC "condemned the serious } \\
\text { violations of human rights and } \\
\text { international humanitarian law carried out } \\
\text { by the Libyan authorities," "expressed } \\
\text { their support ... for the UN Security } \\
\text { Council Resolution No. 1970," and } \\
\text { "called the UN Security Council to } \\
\text { impose an air embargo on Libya to } \\
\text { protect civilians" (8 March 2011). }\end{array}$ & $\begin{array}{l}\text { - The GCC has supported the LAS in its } \\
\text { observation mission in Syria by providing forty- } \\
\text { two of the original set of observers (two with- } \\
\text { drew), and twenty-one vehicles. }\end{array}$ \\
\hline \multicolumn{2}{|c|}{ Group 2 - UNSC Permanent Five (UNSC P5) } \\
\hline \multicolumn{2}{|l|}{ Actor-United States } \\
\hline $\begin{array}{l}\text { - The U.S. Senate passed non-binding } \\
\text { resolution S.RES.85 (1 March 2011) } \\
\text { "strongly condemning the gross and } \\
\text { systematic violations of human rights in } \\
\text { Libya," and "urge[d] the United Nations } \\
\text { Security Council to take such further } \\
\text { action as may be necessary to protect } \\
\text { civilians in Libya from attack." This is the }\end{array}$ & $\begin{array}{l}\text { - The U.S. began to impose sanctions on the } \\
\text { Assad family in April } 2011 .^{35} \\
\text { - The U.S. voted in favor of the first UNSC } \\
\text { draft resolution condemning the Syrian } \\
\text { government (4 October } 2011){ }^{43} \\
\text { - US voted in favor of the second UNSC draft } \\
\text { resolution condemning the Syrian government (4 } \\
\text { February 2012). }{ }^{\text {. }}\end{array}$ \\
\hline
\end{tabular}

28 African Union Communique, "Meeting of the African Union High-Level Ad Hoc Committee on Libya," Addis Ababa, 19 March 2011; available at http://au.int/en/dp/ps/sites/default/ files/Communique_en_19_March_2011_PSD_Meeting_au_High_Level_ad_hoc_committee _Libya_Nouakchott_Islamic_Republic_Mauritania.pdf .

29 African Union Press Release, "Chairperson Ping Receives the Deputy Minister of Foreign Affairs," Addis Ababa, 22 October 2011; available at www.au.int/ar/dp/cpauc/sites/default/ files/Chairperson Ping receives the Deputy Foreign Minister of Syria.pdf.

30 Joint Statement issued by the Joint Ministerial Meeting of the Strategic Dialogue between the Countries of the Cooperation Council for the Arab Gulf States and Australia (Riyadh: Gulf Cooperation Council Secretariat, 8 March 2011); available at http:/www.gcc-sg.org/index c23e.html?action=News\&Sub=ShowOne \&ID=1919. 
first legal document suggesting intervention. $^{31}$

- Voted in favor of UNSCR 1973 (17 March 2011). ${ }^{32}$

- Began enforcing a no-fly zone over Libya with Operation Odyssey Dawn in conjunction with the U.K. and France (19 March 2011), ${ }^{33}$ before passing control to NATO Operation Unified Protector (22 March 2011). ${ }^{34}$

\section{Actor-United Kingdom}

- Voted in favor of UNSCR 1973 (17 March 2011). ${ }^{33}$

- Began enforcing a no-fly zone over Libya with Operation Ellamy in conjunction with France and the U.S. before passing control to NATO Operation Unified Protector (22 March 2011) after the U.K. Parliament approved the application of military assets in a 557 for, 13 against vote (21 March 2011). ${ }^{36}$

- The U.K. has pressed for sanctions, but is focusing primarily on the development of a UNSCR on the issue. ${ }^{37}$

- The U.K. voted in favor of the first UNSC draft resolution condemning the Syrian government (4 October 2011). ${ }^{43}$

- The U.K. voted in favor of the second UNSC draft resolution condemning the Syrian government (4 February 2012). ${ }^{9}$

\section{Actor-France}

- Became the first state to recognize the NTC as Libya's legitimate government (10 March 2011). ${ }^{38}$

- Began enforcing a no-fly zone over Libya with Operation Harmattan (19 March 2011) in conjunction with the U.S. and U.K. before passing control to NATO
- France voted in favor of the first UNSC draft resolution condemning the Syrian government (4 October 2011). ${ }^{43}$

- France's latest push for a UNSC draft resolution was vetoed (4 February 2012) by Russia and China. ${ }^{9}$

31 The White House, Executive Order 13572 (29 April 2011), (Washington, D.C.: Federal Register 76:85, 3 May 2011); available at http://www.treasury.gov/resource-center/sanctions/ Programs/Documents/13572.pdf. United Nations Security Council Resolution, Minutes of the $6498^{\text {th }}$ Meeting of the Security Council, 2011; available at http://daccess-dds-ny.un.org/doc/UNDOC/PRO/N11/267/18/ PDF/N1126718.pdf?OpenElement.

33 Operation Odyssey Dawn (Libya): Background Issues for Congress, CRS Report for Congress (Washington, D.C.: Congressional Research Service, 2011); available at www.fas.org/ sgp/crs/natsec/R41725.pdf. Operation Unified Protector Final Mission Statistics.

35 The White House, Executive Order 13582 (17 August 2011), (Washington, D.C.: Federal Register 76:162, 22 August 2011); available at www.treasury.gov/resource-center/sanctions/ Programs/Documents/syria_eo_08182011.pdf.

36 Claire Taylor, "In Brief: Parliamentary Approval for Deploying the Armed Forces," House of Commons Standard Note SN/IA/5908 (London: House of Commons Library, 7 April 2011); available at www.parliament.uk/briefing-papers/SN05908.pdf.

37 "Syria Unrest: UK, France and Italy Press for Sanctions," BBC World News (26 April 2011); available at www.bbc.co.uk/news/world-middle-east-13197277. 


\begin{tabular}{|c|c|}
\hline $\begin{array}{l}\text { Operation Unified Protector ( } 22 \text { March } \\
\text { 2011). } \\
\text { • Voted in favor of UNSCR } 1973 \text { (17 } \\
\text { March 2011). }{ }^{33} \\
\end{array}$ & \\
\hline \multicolumn{2}{|l|}{ Actor-Russia } \\
\hline $\begin{array}{l}\text { - Russia abstained from the vote on } \\
\text { UNSCR } 1973 \text { (17 March 2011), }{ }^{33} \text { and } \\
\text { later opposed Operation Unified Protector } \\
\text { as an improper exploitation of "fuzzy" } \\
\text { wording in the document's text. Russia } \\
\text { criticized NATO for going beyond R2P to } \\
\text { achieve regime change. }\end{array}$ & $\begin{array}{l}\text { - Russia vetoed the first UNSC draft } \\
\text { resolution on Syria (4 October 2011), citing } \\
\text { "respect for the national sovereignty ... of } \\
\text { Syria," as a concern. } \\
\text { - Russia has vetoed (4 February 2012) the } \\
\text { most recent UNSC draft resolution on Syria, } \\
\text { blaming "international members of the interna- } \\
\text { tional community" (i.e., the U.S., U.K., and } \\
\text { France) for destabilizing the situation by "calling } \\
\text { for regime change, encouraging the opposition } \\
\text { towards power, indulging in provocation and } \\
\text { nurturing the armed struggle," while contra- } \\
\text { dictorily stating that "the bloodshed and violence } \\
\text { in Syria must be immediately ended." } \\
\text { - Russia has suggested informal multilateral } \\
\text { talks without preconditions in Moscow, instead } \\
\text { of at the UN. }{ }^{41}\end{array}$ \\
\hline \multicolumn{2}{|l|}{ Actor-China } \\
\hline $\begin{array}{l}\text { - The People's Republic of China } \\
\text { (PRC) attempted to balance non- } \\
\text { interventionism with support for civilian } \\
\text { protection missions by the Arab League } \\
\text { by abstaining from the vote on UNSCR } \\
1973 \text { (17 March 2011). }\end{array}$ & $\begin{array}{l}\text { - The PRC vetoed the first UNSC draft } \\
\text { resolution on Syria (4 October 2011), stating that } \\
\text { their delegation was "highly concerned about the } \\
\text { developments in Syria," but believed that "under } \\
\text { the current circumstances, sanctions or the threat } \\
\text { thereof does not help to resolve the question of } \\
\text { Syria and, instead, may further complicate the } \\
\text { situation." } 43 \\
\text { - The PRC vetoed the latest UNSC draft } \\
\text { resolution on Syria along with Russia (4 } \\
\text { February 2012), citing respect for the } \\
\text { "sovereignty, independence and territorial } \\
\text { integrity of Syria," as motivation. }\end{array}$ \\
\hline
\end{tabular}

38 "Libya: France Recognises Rebels as Government," BBC News Europe (10 March 2011); available at www.bbc.co.uk/news/world-africa-12699183.

39 Official Statement, French Ministry of Defense, "Libye: point de situation opération Harmat$\tan \mathrm{n}^{\circ} 1$," (25 March 2011); available at www.defense.gouv.fr/operations/autres-operations/ operation-harmattan-libye/actualites/libye-point-de-situation-operation-harmattan-n-1. Evans, "Syrian Forces Break up Hama Protest Marking Killings."

${ }^{41}$ United Nations Press Release, "Security Council Debates Situation in Syria," 31 January 2012; available at www.un.org/apps/news/story.asp? NewsID $=41090 \& C r=S y r i a \& C r 1=$. 


\begin{tabular}{|c|c|}
\hline \multicolumn{2}{|c|}{ Group 3 - Other Notable UNSC Non-Permanent Members } \\
\hline \multicolumn{2}{|l|}{ Actor-India } \\
\hline $\begin{array}{l}\text { - Abstained from the vote on UNSCR } \\
1973 \text { (17 March 2011), voicing concerns } \\
\text { that the intervention would increase } \\
\text { civilian casualties and was aimed more at } \\
\text { regime change than R2P. }{ }^{33}\end{array}$ & $\begin{array}{l}\text { - Abstained from the first UNSC draft } \\
\text { resolution vote (4 October 2011), stating that } \\
\text { "India remains concerned about the unfolding } \\
\text { events in Syria," but "given the complexity of } \\
\text { ground realities in Syria, we believe that } \\
\text { engaging Syria in a collaborative and } \\
\text { constructive dialogue and partnership is the only } \\
\ldots \text { way forward." } 43 \\
\text { - Voted in favor of UNSC draft resolution (4 } \\
\text { February 2012), stating, "We strongly condemn } \\
\text { all violence, irrespective of the perpetrators." } 9\end{array}$ \\
\hline \multicolumn{2}{|l|}{ Actor-Brazil } \\
\hline $\begin{array}{l}\text { Abstained from the vote on UNSCR } \\
1973 \text { (17 March 2011), voicing concerns } \\
\text { that the intervention would increase } \\
\text { civilian casualties and was aimed more at } \\
\text { regime change than R2P. }{ }^{33}\end{array}$ & $\begin{array}{l}\text { - Abstained from the vote on the UNSC draft } \\
\text { resolution (4 October 2011), encouraging a } \\
\text { "meaningful and inclusive national dialogue," } \\
\text { using soft power influence from the "estab- } \\
\text { lishment by the Human Rights Council of a } \\
\text { commission of inquiry," rather than sanctions. } \\
\text { - Was not a member of the UNSC during the } \\
\text { latest UNSC draft resolution vote (4 February } \\
\text { 2012), but worked multilaterally outside of the } \\
\text { UN with South Africa and India to vocally } \\
\text { pressure the Syrian government to reform. }\end{array}$ \\
\hline \multicolumn{2}{|l|}{ Actor-Germany } \\
\hline $\begin{array}{l}\text { Abstained from the vote on UNSCR } \\
1973 \text { (17 March 2011), proposing } \\
\text { political, rather than military pressure to } \\
\text { resolve the Libyan crisis. }{ }^{33} \text { This was a } \\
\text { break from the EU line of support for } \\
\text { pressure on the Libyan government. }\end{array}$ & $\begin{array}{l}\text { - Voted in favor of the first UNSC draft } \\
\text { resolution on Syria (4 October 2011) in } \\
\text { alignment with EU members France, Portugal, } \\
\text { and the U.K. } \\
\text { - Voted in favor of the second UNSC draft } \\
\text { resolution on Syria (4 February 2012) in } \\
\text { alignment with EU members France, Portugal, } \\
\text { and the U.K. }\end{array}$ \\
\hline
\end{tabular}

42 UN Security Council Draft Resolution, 4 October 2011 (minutes of the $6627^{\text {th }}$ meeting of the UNSC); available at http://daccess-dds-ny.un.org/doc/UNDOC/PRO/N11/529/74/PDF/N11 52974.pdf?OpenElement. 


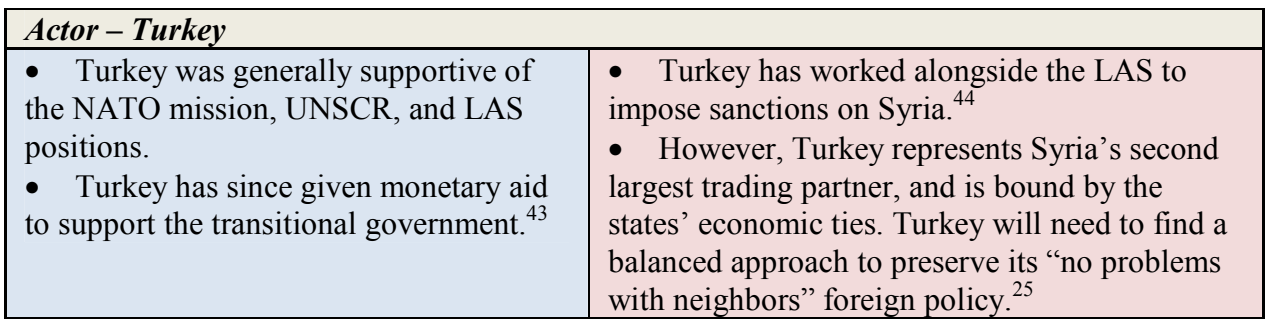

\section{Analysis}

While intended initially as a reference guide, the table above provides several useful insights into the Libyan and Syrian crises. Two interrelated insights are particularly illustrative of underlying global trends: first, a decline from 2011 to 2012 in United States, United Kingdom, and French political will to pursue the Responsibility to Protect (R2P); and second, a reciprocal growing desire from the Russian Federation and China to defend incumbent governments from external intervention.

On the first trend, when comparing LAS involvement in Libya and Syria there appears to be a declining degree of real effort from the three Western members of the five permanent members of the United Nations Security Council to enforce R2P and pursue regime change. In the Libyan case, the U.S. Senate was active in calling for intervention, indirectly citing R2P as a motive. Similarly, the U.K. Parliament was eager to approve funding for a military-enforced no-fly zone. France was quick to recognize the NTC as Libya's legitimate government. All three of these states launched military missions to enforce a no-fly zone over Libya within two days of the UNSC requesting such action (constituting an instantaneous response when measured against the glacial pace of most international orchestration). On the contrary, in the Syrian case this rapid willingness to intervene has been relatively muted. While there has been an active diplomatic effort in the UNSC, representatives have been quick to compromise and dilute proposed resolutions. As a result, the October 2011 and February 2012 UNSC draft resolutions on Syria were much less aggressive in their wording when compared to the UNSCRs aimed at Libya in 2011.There have also been no formal governmental calls for action, as was witnessed in the U.S. Senate in 2011. And there have been no military mobilizations or serious suggestions of enforcing a no-fly zone.

A second, inverse trend can be seen with respect to the other two permanent members of the Security Council, China and Russia, when comparing the cases of Libya 2011 and Syria 2012. The most immediately obvious difference in these two nations' approach toward Syria and Libya has been the decision by China and Russia to veto the 4 October 2011 and 4 February 2012 UNSC draft resolutions on Syria, rather than

43 "Libya: Turkey Recognises Transitional National Council," BBC News Africa (3 July 2011); available at www.bbc.co.uk/news/world-africa-14009206.

44 Dan Bilefsky, "Turkey Moves to Intensify Sanctions Against Syria," The New York Times (30 November 2011); available at www.nytimes.com/2011/12/01/world/middleeast/turkeyintensifies-sanctions-against-syrian-regime.html?ref=arableague. 
to abstain from voting (as they did in the case of UNSCR 1973 and Libya). Moscow and Beijing have clearly placed a greater importance on the defense of the Syrian regime relative to the Libyan government.

\section{Limitations}

The above insights are however, incomplete, and illustrate the limitations of the table in analyzing changing policy trends. The table serves its purpose in identifying what the differences are between both cases, but does not delve into the question of why these differences have developed as they did. Without the "why," and without a broader set of data than these two anecdotal examples, it is also unclear whether these differences represent fundamental policy changes, or if they represent a consistent policy being applied in different forms to address the unique circumstances in Libya and Syria. The following section will attempt to tentatively answer these two follow-up questions: "why," and "what are the implications?" However, further research will be needed to find definitive answers.

\section{Further Assessment}

There are several underlying forces that could explain the "why" in both of the aforementioned trends. With regard to the U.S., U.K., and France's differing approaches, this shift appears to be driven by three dominant constraints: domestic politics, economics, and the international legal environment. Both the U.S. and France will be holding presidential elections in 2012. With the prospect of being voted out of office looming on the horizon, the respective incumbent nominees Barack Obama and Nicolas Sarkozy appear less willing to take risks on major foreign interventions. The second force, economics, involves the fact that the U.S., the U.K., and France are all feeling the burden of the global financial crisis. With domestic demand for government social program spending on the rise and recently announced cuts in defense spending, the costs of foreign intervention now seem too great to justify. Therefore, given current circumstances in the U.S., U.K., and France, there is no longer enough political or monetary capital available to fund interventions. Third, this resource deficit is compounded by the fact that there is not yet any international legal approval for intervention in Syria - unlike the Libyan case, where the international community provided explicit authorization for military action in the form of a UNSCR, a resolution from Libya's affiliated party, the LAS, and consistent affirmations from various state governments that the Qaddafi regime had lost its legitimacy as the sovereign government of Libya. This legal platform to justify action is absent in the Syrian case. The LAS still regards Assad's government as legitimate, if deeply flawed, and the UNSC has not yet provided the approval necessary for R2P operations to begin.

China and Russia's changes in policy seem to be attributable to several driving factors. First, China and Russia have much more substantial military and economic ties to Syria than they did to Libya. Russia's sole Mediterranean naval base is located in Tartus, Syria. Moscow also has approximately USD 20 billion at stake in weapons and infrastructure deals with Damascus. China has its eyes locked on Syria's oil resources, 
and both countries - Russia because of its close proximity, and China because of its insatiable demand for energy resources - have a profound interest in assuring stability in the region, an interest that could be undermined by a collapse of the Assad regime. Furthermore, both countries feel a need to rebuild their international reputations after providing de facto authorization to NATO's enforcement of Western interests in Libya. Having allowed the West to get its way in Libya, both states are now attempting to prove their equal power relative to the West by vetoing any further intervention in the Middle East and North Africa. Evidence for this motive can be witnessed in Russia's bilateral talks with Damascus and proposal that multilateral negotiations take place in Moscow, rather than at the UN. This suggests that Russia does want change in Syria, but wants Russian-managed change, rather than change enforced by the West or other bodies not aligned with Moscow, such as the LAS. There is also an implicit Chinese desire to reassure the world of its non-interventionist foreign policy after having appeared complicit, or at least permissive of, regime change in Libya. By vetoing any Security Council Resolutions on Syria, Russia and China are polishing their international image and reasserting themselves as global powers on par with the West, while countering institutions non-aligned with China or Russia. This could suggest a growing struggle for power-parity along an East-West divide.

Additionally important in China and Russia's recently insistent defense of Syria is the fact that China and Russia both represent governments in a similar situation to the Assad regime: all three states are examples of centralized, non-democratic governments with significant opposition movements that threaten national unity. This "same boat" mentality produces a desire for solidarity. Following a year when Time Magazine chose "the Protestor" as its Person of the Year, China and Russia are worried about the potential implications of another successful revolt on the passivity of their respective populations. There appears to be concern that a domino effect that started in Tunisia in 2011 could spread east to Moscow and Beijing if allowed to continue on its path through Damascus. Russia has seen recent protests against the rigging of national "managed elections," and consistently feels threatened by its Chechen minority population. Similarly, China has experienced the March 2011 Yunnan protest, the April 2011 Shanghai riots, the June 2011 Zencheng riot, and weekly pro-democracy protests in Beijing, and feels persistently threatened by minority populations in western China. Another successful revolt in Damascus could embolden protesters outside of Syria. Thus, assuring the stability of the Syrian regime abroad is regarded by Beijing and Moscow as an investment in domestic security in China and Russia.

\section{Conclusion}

This article is intended chiefly to provide a comprehensive comparison of international developments surrounding the situations in Libya in 2011 and Syria in 2012, thus illustrating any notable differences between them and any changes in policy among relevant actors. The assertions in the previous section about the implications of these differences are, however, only conjectures made in an attempt to fill any informational gaps in the table. Further research will need to be done to definitively understand the 
WINTER 2011

forces behind these policy changes, and to grasp the repercussions these changes will have on the future of foreign policy. 
THE QUARTERLY JOURNAL

\section{Bibliography}

"Libya: France Recognises Rebels as Government." BBC News Europe (2011).

"Libya: Turkey Recognises Transitional National Council." BBC News Africa (2011).

"Syria Unrest: UK, France and Italy Press for Sanctions." BBC World News (2011).

Agreement, Council of the Eur. "Cooperation Agreement between the European Economic Community and the Syrian Arab Republic." Brussels: Official Journal of the European Communities (1977).

Bilefsky, Dan. "Turkey Moves to Intensify Sanctions Against Syria." The New York Times (2011).

Defense, French Ministry o. Libye: point de situation opération Harmattan $n^{\circ} 1$., 2011.

Taylor, Claire. In Brief: Parliamentary Approval for Deploying the Armed Forces. House of Commons Standard Note SN/IA/5908 (Lon $\neg$ don: House of Commons Library, 2011.

Zein, H.. "Syria Rejects Decisions of AL Ministerial Meeting as Flagrant Interference in Syria's Affairs \& Encroachment on its National Sovereignty." Sana Syria News Agency (2012). 